\title{
Growth temperature and plant age influence on nutritional quality of Amaranthus leaves and seed germination capacity\#
}

\author{
Albert T Modi* \\ Crop Science, School of Agricultural Sciences and Agribusiness, University of KwaZulu-Natal, Private Bag X01, \\ Scottsville 3201, South Africa
}

\begin{abstract}
As a leafy vegetable, Amaranthus can be harvested at different stages of plant growth, ranging from young seedlings to the late juvenile stage, but data on the changes in leaf nutritional value with plant age are scanty. The objective of this study was to determine the effect of growth temperature on Amaranthus leaf yield and nutritional quality at different stages of plant growth. Five species, A. hybridus var. cruentus, A. hypochondriacus, A. tricolor, A. thunbergii and A. hybridus were compared for their response to hot $\left(33 / 27^{\circ} \mathrm{C}\right)$, warm $\left(27 / 21^{\circ} \mathrm{C}\right)$ and $\operatorname{cool}\left(21 / 15^{\circ} \mathrm{C}\right)$ temperature regimes (day/night) in separate glasshouses. Plants were harvested at 20, 40 and $60 \mathrm{~d}$ after sowing and leaf yield, minerals (Ca, P and Fe), total protein content, amino acid (methionine and lysine) content and antioxidant activity (inhibition of linoleic acid oxidation) were determined. Seed yield and germination capacity, during two years of after-ripening, were also determined. Results showed that leaf protein content differed significantly $(\mathrm{P}<0.01)$ between species. It was also significantly $(\mathrm{P}<0.01)$ influenced by the growth temperature and stage of plant growth. The pattern of changes in the amounts of lysine and methionine was comparable to that of protein content, but $A$. thunbergii showed significantly higher amino acid content than the other species. Amaranthus leaves also contained significantly $(\mathrm{P}<0.01)$ more lysine than methionine, regardless of the species and growth temperature. The phosphorus content of leaves was not significantly affected by temperature and stage of plant development, and there were also no significant differences between species. However, the amounts of both calcium and iron changed significantly $(\mathrm{P}<0.05)$ with stages of plant development and with increasing temperatures for all species. The antioxidant activity of Amaranthus leaves increased consistently with plant age and there were significant $(\mathrm{P}<0.01)$ differences between stages of plant development and growth temperature. Warm temperature regimes were most favourable $(\mathrm{P}<0.01)$ for biomass accumulation in all species. Seed production under cool and hot temperatures significantly $(\mathrm{P}<0.01)$ decreased seed germination capacity for all species, but germination improved in response to after-ripening. It is recommended that for greater nutritional benefit, Amaranthus should be grown under warm conditions and younger leaves are preferable.
\end{abstract}

Keywords: Amaranthus, leaf nutrients, plant age, temperature

\section{Introduction}

The maturity stage of a conventional vegetable is universally defined, and a crop is normally harvested and consumed at a known stage of plant development, irrespective of environmental conditions for plant growth. Hence, data on the nutritional content of conventional vegetables can be reasonably associated with a specific stage of plant development. Unlike conventional vegetables, there is no documented information about the stage of plant development to define harvest maturity for wild leafy vegetables. Hence data on their nutritional value is likely to vary widely (Guarino, 1997; Jansen van Rensburg et al., 2004; Kruger et al., 1998), due to influences of plant age and the environmental conditions during plant growth.

Wild leafy vegetables are harvested by rural communities from crop fields or from the veld at different stages of plant growth (Modi et al., 2006). It is likely that for some wild leafy vegetables there is a preferred stage of plant development when flavour and palatability are favourable for human consumption.

* Revised version. Originally presented at the International Symposium on the Nutritional Value and Water Use of Indigenous Crops for Improved Livelihoods held on 19 and 20 September 2006 at the University of Pretoria in Pretoria, South Africa.

* I표 +27 …………….....................; fax: +27 33-260-5073; e-mail: modiat@ukzn.ac.za
Food insecurity pressures (e.g. lack of food or vegetables) and other factors associated with human preference (e.g. age, gender and culture) may also influence the stage of plant development when wild leafy vegetables are harvested and consumed (Mathenge, 1997). It is also likely that for some wild leafy vegetables, flavour and palatability are not significantly affected by plant phenostage. For most conventional crops it has been established that the effects of environmental conditions during plant growth differ with plant age (Stahl and McCree, 1988), and management practices for these crops are normally in congruence with environmental requirements at different stages of plant growth. However, evidence of an interaction between environment and plant age for crop nutrient status is scanty (Wang and Zheng, 2001).

Amaranthus species are probably the most widely occurring leafy vegetables in South Africa and Africa in general (Guarino, 1997; Jansen van Rensburg et al., 2004), and data on the nutritional value of Amaranthus are available in literature (Guarino, 1997; Jansen van Rensburg et al., 2004; Kruger et al., 1998). The premise of this study was a postulation that environmental conditions during plant growth and plant age interact to influence the nutritional value of wild leafy vegetables. To test the hypothesis, the objective of this study was to examine the effect of three day/night temperature combinations, under controlled environment conditions, on the content of selected nutrients in Amaranthus leaves harvested at three stages of plant development. 


\section{Experimental}

Seeds of Amaranthus hybridus var. cruentus, A. hypochondriacus and A. tricolor were donated by Professor A.L.P. Cairns from the Crop Science Department, University of KwaZuluNatal. Seeds of $A$. thunbergii and A. hybridus were collected from a homestead in Umbumbulu, KwaZulu-Natal. Seeds were sown in pots containing $2.5 \mathrm{~kg}$ loamy top soil of the Ntsubane soil family of the Magwa form (Soil Classification Working Group, 1991) collected from Umbumbulu. Prior to sowing, the soil was fertilised with 2:3:2 (22) fertilizer at a rate of $40 \mathrm{~kg} \cdot \mathrm{ha}^{-1}$ $\mathrm{N}, 60 \mathrm{~kg} \cdot \mathrm{ha}^{-1} \mathrm{P}$ and $40 \mathrm{~kg} \cdot \mathrm{ha}^{-1} \mathrm{~K}$, respectively. Fertiliser recommendation was based on soil nutrient analysis and the nutrient requirements for cabbage (Brassica oleracea) (Manson et al., 2004). Seedlings were thinned to one plant per pot and placed in three different glasshouses at day/night temperature conditions designated as hot $\left(33 / 27^{\circ} \mathrm{C}\right)$, warm $\left(27 / 21^{\circ} \mathrm{C}\right)$ and cool $\left(21 / 15^{\circ} \mathrm{C}\right)$, respectively. Irrigation was applied manually at $100 \mathrm{~m} \ell$ per pot per day for the first two weeks and $200 \mathrm{~m} \ell$ per pot per day from the third week after sowing to $\sim 80 \%$ leaf senescence to satisfy cabbage irrigation requirements (Smith, 2006). The pots were sealed to prevent water leakage from the bottoms.

Leaves were sampled $20 \mathrm{~d}, 40 \mathrm{~d}$ and $60 \mathrm{~d}$ after sowing (DAS) respectively, by removing all the leaves from a plant and determining the fresh mass, total protein, methionine and lysine (Modi, 2002). Mineral nutrients, Ca, Fe and P, were determined as described by Mazibuko and Modi (2005). To investigate the antioxidant potential of Amaranthus leaves, inhibition of linoleic acid oxidation was determined in boiled extracts as described by Lindsey et al. (2002). One hundred and twenty days after sowing, seeds were harvested manually by cutting inflorescences and placing them in brown paper bags. Seeds were separated from the inflorescences by shaking and rubbing the inflorescence. Chaff was removed by repeated sieving $(2 \mathrm{~mm})$ and hand separation. To determine the effect of temperature on seed potential for crop establishment, germination capacity of fresh seeds was tested (AOSA, 1993). Subsequent germination tests were performed every year for two years of dry storage in brown paper bags at room temperature (after-ripening).

The experiment was a $3 \times 5 \times 3$ completely random factorial design with the factors being temperature (hot, warm and cool), Amaranthus species (Amaranthus hybridus, A. hybridus var. cruentus, A. hypochondriacus, A. tricolor and A. thunbergii) and stage of plant development (20, 40 and 60 DAS). The experiment was replicated five times. In addition, there were five replications of each species for determination of seed yield. Hence, there were 100 pots in each glasshouse, 75 pots for continuous sampling to determine leaf nutritional quality and 25 pots for seed yield determination. Treatment effects were determined by analysis of variance (Genstat Statistical Package, Rothamsted, $\mathrm{UK})$ at $\mathrm{P} \leq 0.05$.

\section{Results and discussion}

\section{Total protein content}

Leaf protein content differed significantly $(\mathrm{P}<0.01)$ between species, with Amaranthus thunbergii consistently showing a higher amount of leaf protein than the other species, regardless of plant age and growth temperature (Fig. 1). Leaf protein content was also significantly $(\mathrm{P}<0.01)$ influenced by the stage of plant development (Fig. 1). The protein content decreased as plant age progressed (Fig. 1). Leaf protein content was also influenced by the growth temperature. At all stages of plant development, hot temperature conditions caused a significant decrease $(\mathrm{P}<$ 0.05) in leaf protein content (Fig. 1). The effect of temperature on leaf protein content observed in this study can be ascribed to the normal regulation of plant tissue maintenance (Lavigne and Ryan, 1997). Higher temperatures increase maintenance respiration at the expense of growth respiration (Covey-Crump et al., 2007; Penning de Vries et al., 1979). Hence, in the present study, higher leaf protein turnover under high-temperature conditions than under cool conditions may have been responsible for the lower protein contents under higher temperature growth conditions (Fig. 1).

\section{Lysine and methionine}

The pattern of changes in the amounts of lysine and methionine in Amaranthus leaves was comparable to that of protein content (Fig. 1) with respect to species differences and the effects of temperature (Fig. 2). The superiority of $A$. thunbergii to the other species with respect to amino acid content was also evident (Fig. 2). It is also evident from Fig. 2 that Amaranthus leaves contained significantly $(\mathrm{P}<0.01)$ more lysine than methionine.

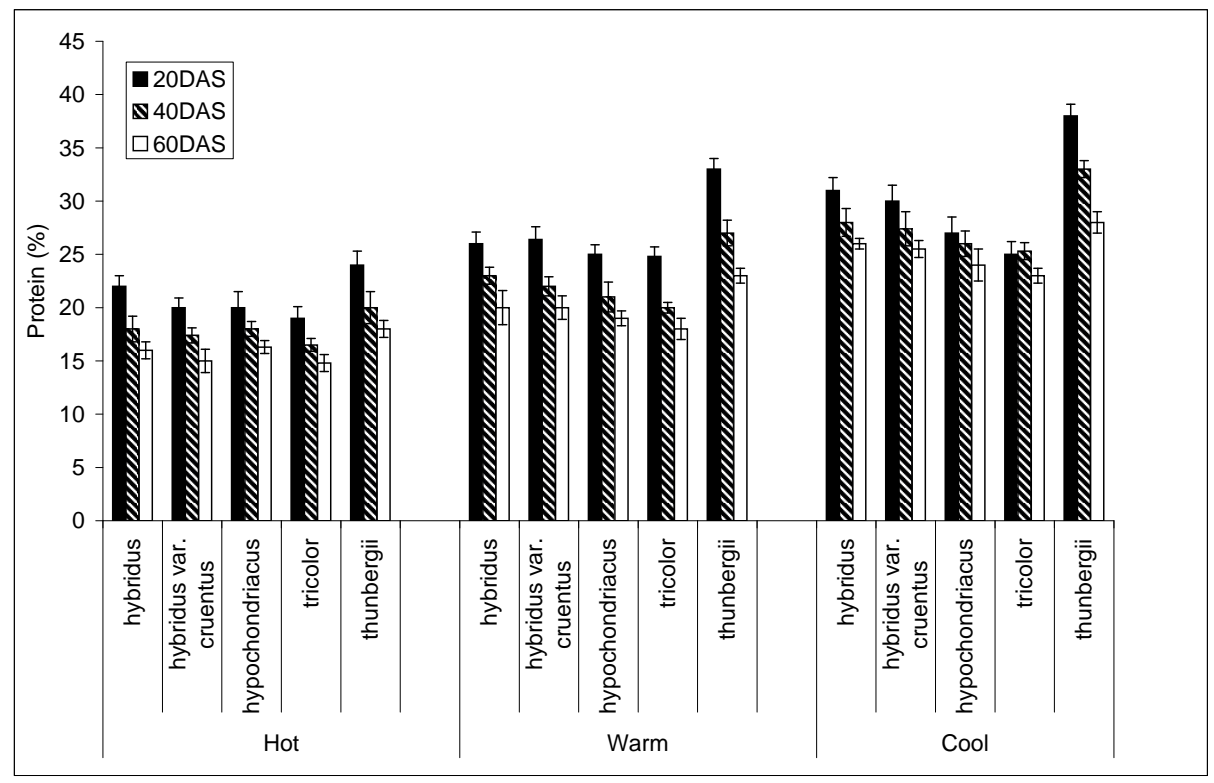

Figure 1

Leaf protein content of different Amaranthus species grown under hot $\left(33 / 27^{\circ} \mathrm{C}\right.$ day/night), warm $\left(27 / 21^{\circ} \mathrm{C}\right.$ day/night) and cool $\left(21 / 15^{\circ} \mathrm{C}\right.$ day/night) conditions and harvested at 20 40 , and 60 days after sowing (DAS), respectively. 


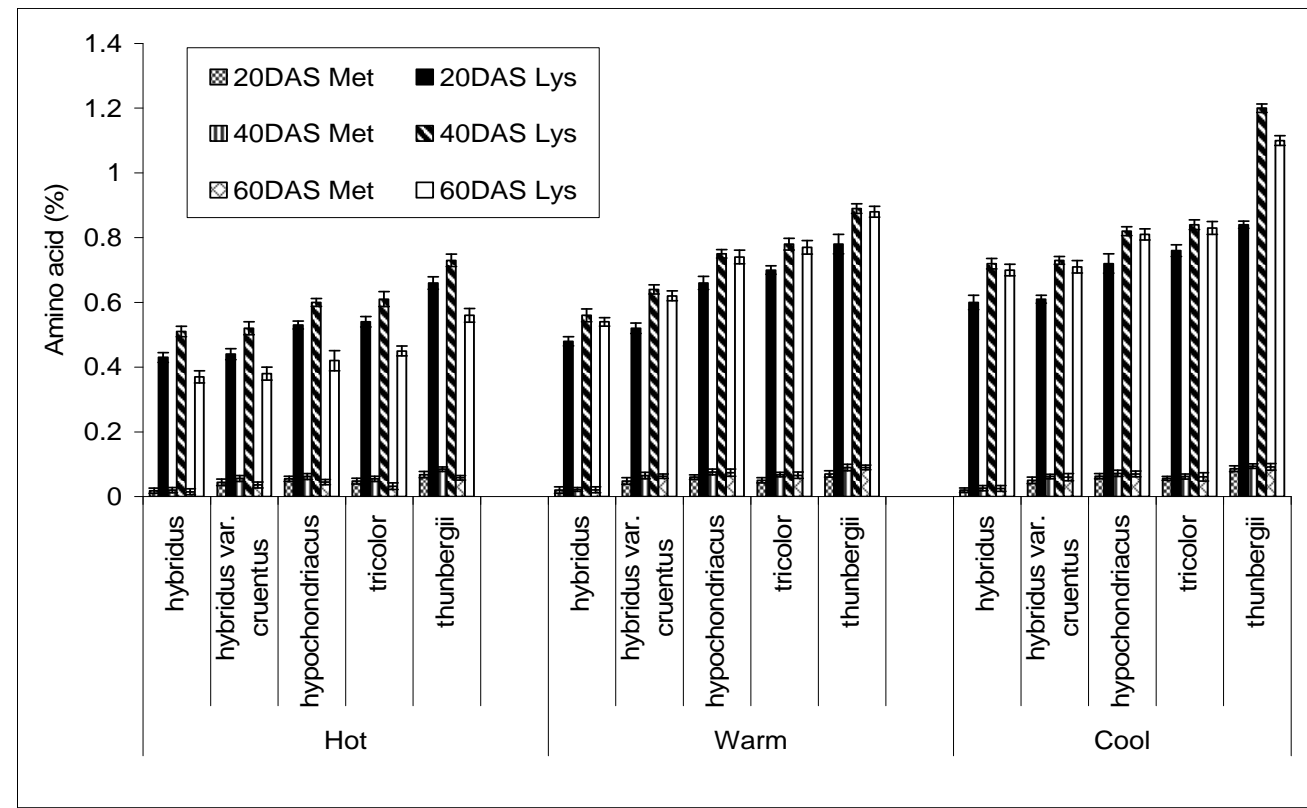

Figure 2

Amino acid (Met and Lys) content in the leaves of different Amaranthus species grown under hot (33/270 C day/ night), warm $\left(27 / 21^{\circ} \mathrm{C}\right.$ day/night) and cool (21/15 $\mathrm{C}$ day/night) conditions and harvested at 20, 40, and 60 days after sowing (DAS), respectively.

The differences between the amounts of lysine and methionine found in this study are in agreement with previously published data on Amaranthus and other species (FAO, 1981), where it was shown that the lysine content of leaf material is generally higher than that of methionine. From the human and animal nutrition perspective, the significance of the findings about lysine and methionine (Fig. 2) is that cereal grains are deficient in lysine (and tryptophan) and legumes are deficient in methionine (and cysteine) (Altenbach and Simpson, 1990). Animal nutritionists have provided specific data on the most important deficiencies when particular grains are used as feed for particular animals. For example, Fernandez et al. (1994) reported that for young chickens the limiting amino acids in maize are lysine, threonine, tryptophan, arginine, isoleucine, valine, cysteine and methionine. When maize and legume grains (soybean in particular) are mixed, the result is sufficiency in methionine, threonine, lysine, valine, arginine and tryptophan (Fernandez et al., 1994). Feed formulation is thus a complex science in itself, and in practice different grains are mixed depending on the composition, energy content and other factors, including price, along with lysine and methionine produced through fermentation. This complexity provides economic incentives to add value to grains by increasing the content of limiting amino acids.

In less developed countries and resource-poor communities, dependence on particular staple crops (e.g. maize in South Africa) for a large part of the diet means that humans could directly benefit from food grains that are rich in limiting amino acids such as lysine and methionine. Although this study did not show the amount of amino acids in Amaranthus grains, it has been reported that grain Amaranthus contains high levels of lysine than other cereal grains (Stallknecht and Schulz-Shaeffer, 1991). Two of the five species reported in the present study, $A$. hybridus var. cruentus, and $A$. hypochondriacus are grain amaranths that can also be produced as leafy vegetables (Teutonico and Knorr, 1985). It has been reported that when grain Amaranthus flour is mixed (30:70) with rice, maize or wheat flour, the protein quality (based on casein) rises from 72 to 90,58 to 81, and 32 to 52, respectively (Bressani, 1989). From the results of this study (Fig. 2) it can be suggested that using Amaranthus leaves to supplement the maize-dominated staple diet of the majority of South Africans would improve food nutritional value, with respect to amino acid composition.

\section{Mineral nutrients}

The phosphorus concentration in Amaranthus leaves was not significantly affected by temperature and stage of plant development, and there were also no significant differences between species (data not shown). However, the concentrations of both calcium and iron differed significantly $(\mathrm{P}<0.05)$ with plant age and with increasing temperature for all species (Table 1). The calcium concentration in Amaranthus leaves increased significantly with plant age from 20 DAS to 60 DAS (Table 1). The iron concentration increased significantly $(\mathrm{P}<0.05)$ only between 20 DAS and 40 DAS, while the difference between 40 DAS and 60 DAS was not significant (Table 1). For both calcium and iron these trends according to plant age were found at each of the three growth temperature regimes (Table 1).

At each of the three growth stages both calcium and iron concentrations in Amaranthus leaves increased with increasing temperature (Table 1). In the case of iron it was a small linear increase. In the case of calcium the increase in calcium concentration in Amaranthus leaves between the cool and warm (intermediate) temperature regimes was marked at each age.

From the perspective of human and animal nutrition, the results shown in Table 1 suggest that more calcium and iron would be found in the leaves of older Amaranthus plants that grow under warm to hot conditions than those which grown under cool conditions. However, the low palatability and digestibility of older leaves may not favour large amounts of Amaranthus leaf intake. It is also likely that older leaves may contain anti-nutrients (e.g. oxalate and phytate) that decrease mineral 
TABLE 1

Calcium and iron content in the leaves of different Amaranthus species grown under hot $\left(33 / 27^{\circ} \mathrm{C}\right.$ day/night), warm $\left(27 / 21^{\circ} \mathrm{C}\right.$ day/night $)$ and $\operatorname{cool}\left(21 / 15^{\circ} \mathrm{C}\right.$ day/night) conditions and harvested at 20,40 , and 60 days after sowing (DAS), respectively. Values in parentheses are standard errors of the mean ( \pm s.e.).

\begin{tabular}{|c|c|c|c|c|c|c|c|}
\hline \multirow[t]{4}{*}{ Temperature } & \multirow[t]{4}{*}{ Species } & \multicolumn{6}{|c|}{ Days after sowing } \\
\hline & & \multicolumn{2}{|c|}{20} & \multicolumn{2}{|c|}{40} & \multicolumn{2}{|c|}{60} \\
\hline & & Calcium & Iron & Calcium & Iron & Calcium & Iron \\
\hline & & \multicolumn{6}{|c|}{$\mathrm{mg} \mathrm{100g} \mathrm{dry} \mathrm{mass}^{-1}$} \\
\hline \multirow[t]{5}{*}{ Hot } & A. hybridus & $42( \pm 1.5)$ & $75 \pm 3.6)$ & $53( \pm 2.2)$ & $90( \pm 3.8)$ & $58 \pm 2.1)$ & $99( \pm 2.9)$ \\
\hline & A. hybridus var. cruentus & $42( \pm 1.7)$ & $45( \pm 2.1)$ & $50( \pm 2.0)$ & $60( \pm 2.5)$ & $54( \pm 2.1)$ & $65( \pm 3.1)$ \\
\hline & A. hypochondriacus & $62( \pm 2.1)$ & $28( \pm 1.8)$ & $71( \pm 2.2)$ & $35( \pm 1.5)$ & $75( \pm 3.1)$ & $38( \pm 2.2)$ \\
\hline & A. tricolor & $55( \pm 2.3)$ & $16( \pm 1.2)$ & $63( \pm 2.4)$ & $20( \pm 1.8)$ & $68( \pm 1.5)$ & $28( \pm 2.3)$ \\
\hline & A. thunbergii & $52( \pm 2.2)$ & $60( \pm 2.2)$ & $61 \pm(2.3)$ & $75( \pm 3.7)$ & $66( \pm 2.6)$ & $89( \pm 2.8)$ \\
\hline \multicolumn{2}{|l|}{ Mean ( \pm s.e.) } & 51(3.8) & $45(10.6)$ & $60(3.7)$ & $56(12.8)$ & $64(3.7)$ & 64 (13.9) \\
\hline \multirow[t]{5}{*}{ Warm } & A. hybridus & $40( \pm 1.8)$ & $70( \pm 3.5)$ & $48( \pm 2.4)$ & $89( \pm 3.1)$ & $54( \pm 3.1)$ & $93( \pm 2.4)$ \\
\hline & A. hybridus var. cruentus & $39( \pm 2.0)$ & $40( \pm 2.5)$ & $46( \pm 2.8)$ & $58( \pm 2.1)$ & $50( \pm 2.5)$ & $62( \pm 2.0)$ \\
\hline & A. hypochondriacus & $58( \pm 1.7)$ & $25( \pm 1.8)$ & $66( \pm 3.3)$ & $31( \pm 1.8)$ & $70( \pm 3.1)$ & $34( \pm 2.1)$ \\
\hline & A. tricolor & $51( \pm 2.1)$ & $14( \pm 2.6)$ & $60( \pm 2.2)$ & $18( \pm 1.4)$ & $63( \pm 2.1)$ & $22( \pm 1.8)$ \\
\hline & A. thunbergii & $48( \pm 1.4)$ & $55( \pm 2.3)$ & $56( \pm 2.4)$ & $80( \pm 3.6)$ & $60(2.3)$ & $84(2.2)$ \\
\hline \multicolumn{2}{|l|}{ Mean ( \pm s.e.) } & $47(3.6)$ & $41(10.1)$ & $55(3.7)$ & 55 (13.7) & $59(3.5)$ & 59 (13.8) \\
\hline \multirow[t]{5}{*}{ Cool } & A. hybridus & $31( \pm 1.2)$ & $65( \pm 3.1)$ & $40( \pm 2.1)$ & $84( \pm 1.8)$ & $44( \pm 2.4)$ & $86( \pm 1.6)$ \\
\hline & A. hybridus var. cruentus & $32( \pm 2.1)$ & $34( \pm 1.9)$ & $41( \pm 1.9)$ & $54( \pm 2.3)$ & $45( \pm 2.6)$ & $58( \pm 2.2)$ \\
\hline & A. hypochondriacus & $47 \pm(2.4)$ & $21( \pm 1.4)$ & $57( \pm 2.1)$ & $28( \pm 1.3)$ & $61( \pm 1.9)$ & $32( \pm 2.0)$ \\
\hline & A. tricolor & $42( \pm 2.5)$ & $13( \pm 1.1)$ & $53( \pm 2.0)$ & $17( \pm 1.4)$ & $56(1.7)$ & $20(1.2)$ \\
\hline & A. thunbergii & $38( \pm 2.6)$ & $50( \pm 2.5)$ & $46( \pm 2.5)$ & $76( \pm 2.0)$ & $51( \pm 1.3)$ & $79( \pm 1.7)$ \\
\hline \multicolumn{2}{|l|}{ Mean ( \pm s.e.) } & $38(3.0)$ & $37(9.5)$ & 47 (3.3) & 52 (13.1) & $51(3.2)$ & 55 (12.9) \\
\hline
\end{tabular}

nutrient bio-availability to humans and animals (Ross and Graham, 1999). For example: Fincham et al. (1986) found that the maize and groundnut diet of the local population in the Mseleni area of Maputoland in northern KwaZulu-Natal is severely deficient in calcium, but that the "wild spinach" (Amaranthus), which is another important dietary item in the area, has a high calcium content. They point out that the latter is, however, also high in fibre, oxalate and phytate, all of which, according to them, interfere with calcium absorption and lower its bio-availability (Fincham et al., 1986).

The rate of water absorption in plants is directly proportional to the atmospheric demand for water (Salisbury and Ross, 1992). High temperatures are likely to have decreased the moisture content of the air in the glasshouse, thus increasing evapotranspiration. Under these conditions, it would be expected that the amount of water absorbed should be lowest under cool temperatures and highest under warm temperatures. Since nutrient absorption from the soil solution occurs concomitantly with water absorption, it is not surprising that the amount of leaf nutrients in well-watered plants would increase as more water moves through the leaves. Since Amaranthus is a C4 plant, it does exercise stomatal control (closure of stomata under harsh conditions) and is thus able to continue stomatal conductance under such conditions (Olavi et al., 2002).

\section{Inhibition of linoleic acid oxidation}

The antioxidant activity of Amaranthus leaves, as determined by inhibition of linoleic acid oxidation, increased consistently with plant age (Fig. 3) and there were significant $(\mathrm{P}<0.01)$ differences between stages of plant development. Regardless of the species, there were no significant differences between 20 DAS and 40 DAS under cool and warm conditions, but under hot conditions there were significant differences $(\mathrm{P}<$ 0.05 ) between all stages of plant development (Fig. 3). The antioxidant activity also increased significantly $(\mathrm{P}<0.01)$ in response to an increase in growth temperature from cool to warm, but it declined to levels even lower than those found under cool conditions in response to hot conditions (Fig. 3). There was a significant $(\mathrm{P}<0.05)$ interaction between plant age and temperature, with respect to leaf antioxidant activity. For example, when cool and warm conditions were compared at 20 DAS, 40 DAS and 60 DAS, A. thunbergii showed antioxidant activity increases of $17 \%, 18 \%$ and $20 \%$, respectively. With the decline in antioxidant activity that occurred in response to a further increase in temperature from warm to hot, the differences shown by $A$. thunbergii for the same stages (20 DAS, 40 DAS and 60 DAS) were $36 \%, 27 \%$ and $28 \%$, respectively. Therefore, it can be suggested that the gain in antioxidant activity of Amaranthus leaves due to warm growth temperatures will be positive, but its extent may be dependent upon the stage of plant development when the leaves are harvested. Further, it can be suggested that the negative effect of hot temperatures on antioxidant activity is more severe for young leaves (20 DAS) compared with older leaves (40 DAS and 60 DAS).

The general pattern of changes in antioxidant activity in response to plant age and temperature was the same for all species, but there were significant $(\mathrm{P}<0.05)$ differences between species (Fig. 3). Across all temperatures and stages of plant development, A. thunbergii displayed the highest $(\mathrm{P}<0.05)$ levels of antioxidant activity compared with the other species (Fig. 3). However, there was no clear ranking of the other four species, behind $A$. thunbergii, because of the significant $(\mathrm{P}<$ 0.01 ) stage $X$ temperature interaction. An attempt to associate the antioxidant activity of the species with agronomic use, which is grain amaranth (A. hybridus var. cruentus, and 
A. hypochondriacus) and vegetable amaranth (the rest of the species), was not successful either. Notable was that the species for which seeds were sourced from the KZN rural area (A. thurnbergii and A. hybridus) showed greater antioxidant activity, albeit not consistently significant across temperatures and stages of development, than the species for which seeds were originally imported (A. tricolour, A. hybridus var. cruentus, and $A$. hypochondriacus). However, this observation is not enough to suggest that the local species are better in antioxidant activity than the imported ones, because the imported species do occur wildly in KwaZulu-Natal and the rest of South Africa (Jansen van Rensburg et al., 2004).

It is well known that vegetable oils, nuts, and green leafy vegetables are dietary sources of antioxidants, such as Vitamin E. The findings of this study confirmed that Amaranthus leaves are important sources of antioxidants, but it would be important to identify the major antioxidants in amaranth leaves that respond to growth temperature at different stages of plant development. That information would be useful for agricultural advisers and human nutritionists.

\section{Biomass and seed production}

Warm temperature conditions were most favourable $(\mathrm{P}<0.01)$ for biomass accumulation in all species (Fig. 4). Cool temperatures were associated with slow biomass accumulation (Fig. 4). Hot temperatures were initially (20 DAS) comparable to the warm conditions, with respect to biomass accumulation, but by 40 DAS there was a significant negative effect of hot temperatures on plant growth (Fig. 4).

All species displayed an increase in seed production in response to warm temperatures, but hot temperatures caused a decline in seed yield (Fig. 5). There were significant $(\mathrm{P}<$ $0.05)$ differences between species, and the grain amaranths ( $A$. hybridus var. cruentus, and $A$. hypochondriacus) showed greater seed yield than the vegetable amaranths (the rest of species) at all growth temperatures (Fig. 5). Amaranthus hypochondriacus, produced more $(20 \%, 11 \%$ and $10 \%$ under cool, warm and hot conditions, respectively) seeds than $A$. hybridus var. cruentus (Fig. 5). The yield response to growth temperatures may be explained by the positive relationship between photosynthesis
Figure 3

Inhibition of linoleic acid oxidation by boiled extracts from leaves of different Amaranthus species grown under hot $\left(33 / 27^{\circ} \mathrm{C}\right.$ day/night), warm $\left(27 / 21^{\circ} \mathrm{C}\right.$ day/ night) and cool $\left(21 / 15^{\circ} \mathrm{C}\right.$ day/night) conditions and harvested at 20 , 40 , and 60 days after sowing (DAS), respectively.
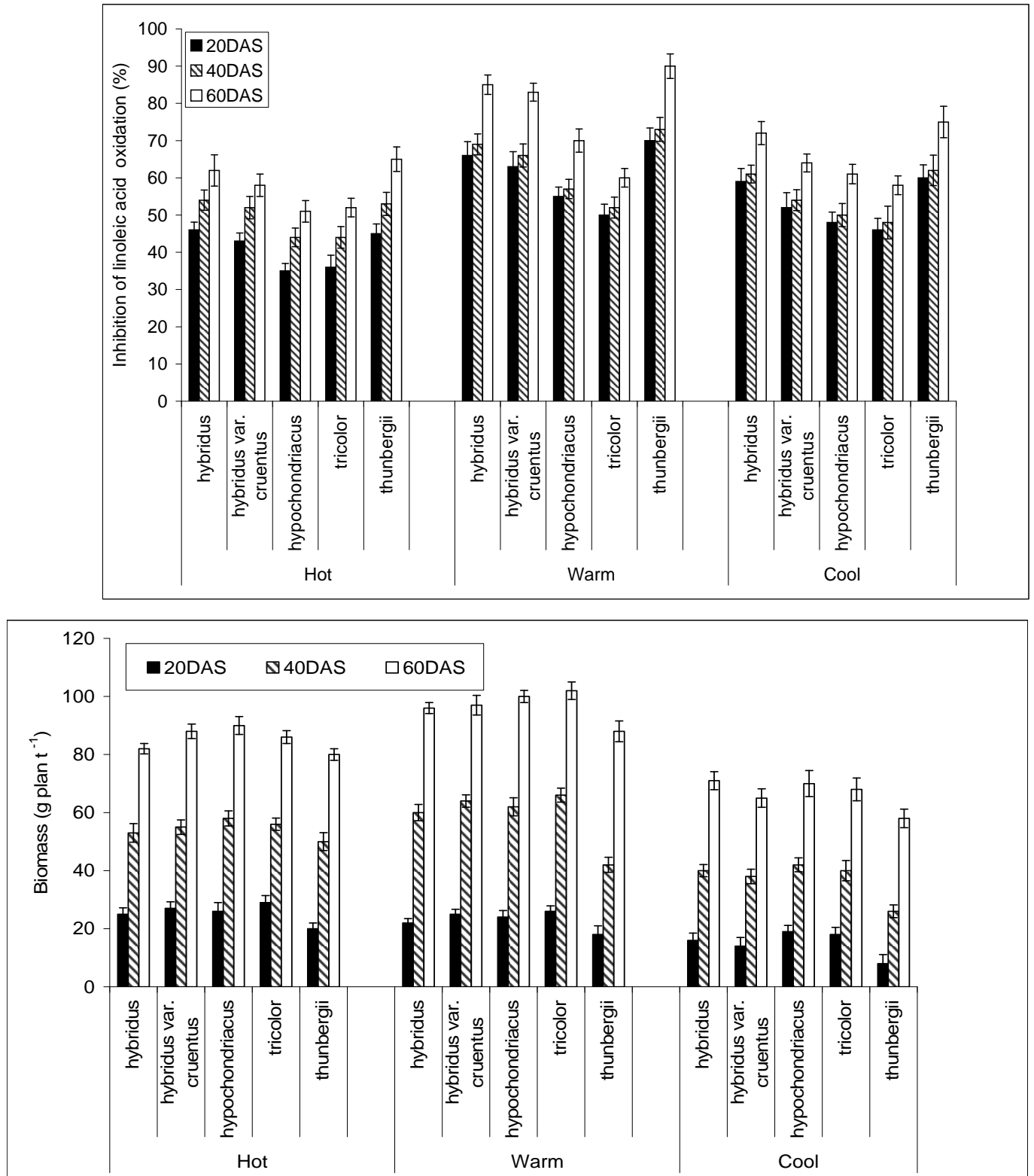
and temperature. Low temperatures are known to have a more negative effect on C4 plants (such as Amaranthus) compared with C3 plants (Salisbury and Ross, 1992). The decrease in yield under hot conditions suggested that the temperatures may have been excessive for growth, and less assimilates were transferred to the seeds. High temperatures during seed development have been shown to cause poor seed production (Wardlaw et al., 1989).

Seed production under cool and hot temperatures significantly $(\mathrm{P}<0.01)$ decreased seed germination capacity for all species, but germination improved in response to after-ripening for one or two years (Fig. 5), depending on the species. There were significant differences $(\mathrm{P}<0.05)$ between species with respect to germination capacity. A. thunbergii, showed the lowest germination capacity in response to all growth temperatures, and it responded the poorest to the dormancy-breaking afterripening. The grain amaranths (A. hybridus var. cruentus, and A. hypochondriacus) had a significantly better germination capacity and responded quickly to after-ripening compared with the vegetable amaranths (Fig. 5).

The effects of growth temperature on seed germination observed in this study have implications for the potential of
Amaranthus seeds for crop establishment and germ-plasm preservation. It is clear from Fig. 6 that fresh Amaranthus seeds have a low potential for crop establishment, because of dormancy. That dormancy may be exacerbated by cool and hot growing conditions, but the dormancy associated with cool temperatures was broken easily by after-ripening compared with dormancy due to hot temperatures (Fig. 6). Therefore, seeds produced under hot environmental conditions may have poor quality for long term storage (germ-plasm preservation), and the poor germination of those seeds may cause loss of germ-plasm due to poor stand establishment.

\section{Conclusion}

This study showed that the nutritional value of Amaranthus leaves is significantly influenced by the growth temperature and stage of development at which the plant is harvested. Cool environmental conditions were found to be associated with high content of total protein and amino acid concentration in the leaves. However, mineral nutrients, calcium and iron increased in the leaves in response to increasing growth temperature. Growth temperature and stage of plant development for leaf harvest were
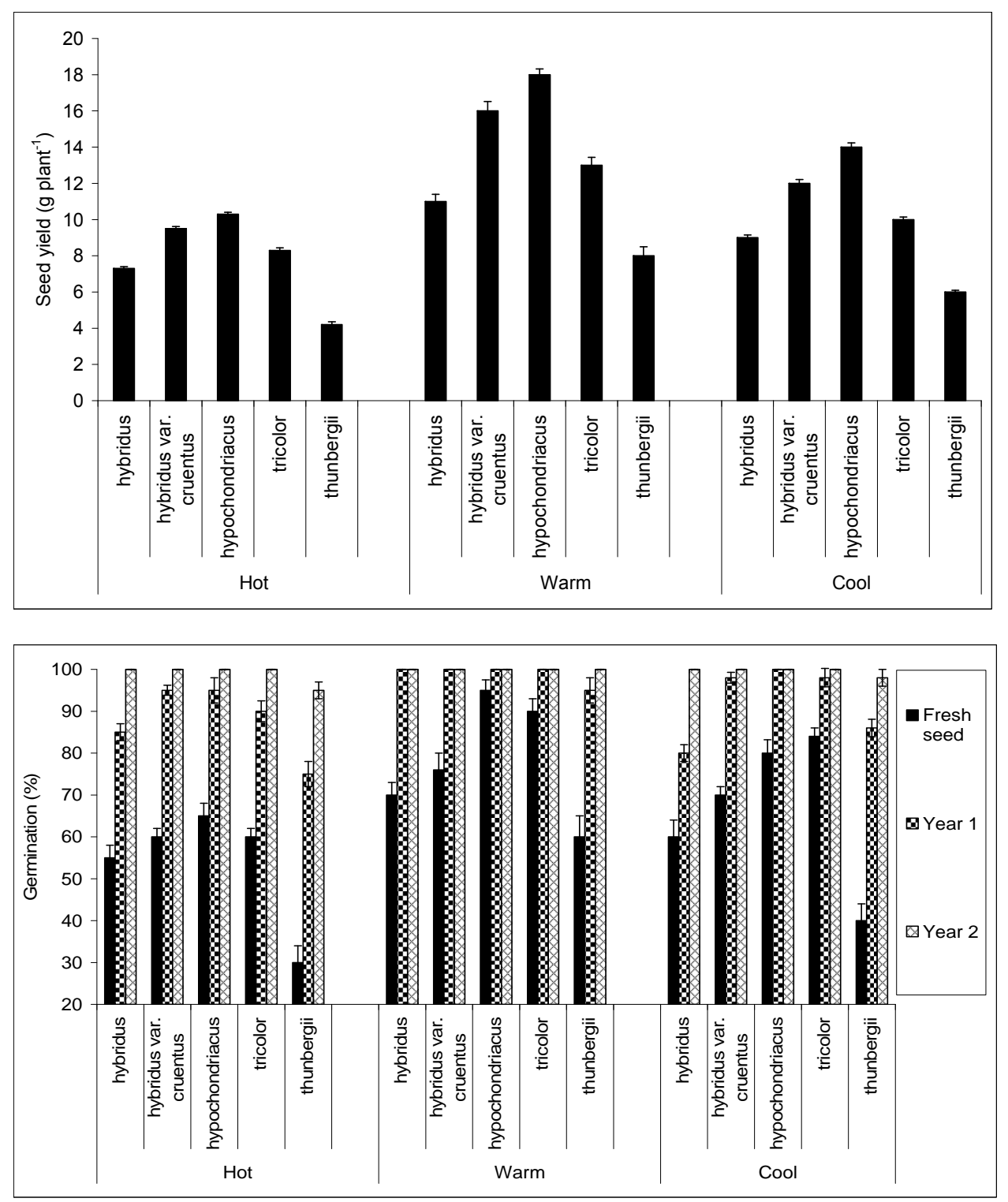

Figure 5

Seed yield of different Amaranthus species grown under hot $\left(33 / 27^{\circ} \mathrm{C}\right.$ day/night), warm $\left(27 / 21^{\circ} \mathrm{C}\right.$ day/night) and cool $\left(21 / 15^{\circ} \mathrm{C}\right.$ day/night) conditions, respectively.

Figure 6

Seed germination capacity of different Amaranthus species tested immediately after harvest maturity (fresh seed) or after one (Year 1) or two (Year 2) years of afterripening. Seeds were harvested from plants grown under hot $\left(33 / 27^{\circ} \mathrm{C}\right.$ day/night), warm $\left(27 / 21^{\circ} \mathrm{C}\right.$ day/night) and cool (21/15 ${ }^{\circ} \mathrm{C}$ day/night) conditions, respectively. 
also found to have a significant effect on the health quality of Amaranthus leaves, the potential for antioxidant activity. It is recommended that for greater nutritional benefit, Amaranthus should be grown under warm conditions and that leaves should preferably be harvested at young growth stages (20 d after sowing). Warm temperatures are associated with high yield and improved germination capacity. The indigenous species, A. thunbergii, was found to contain the highest levels of total protein, amino acids (lysine and methionine) and antioxidant potential compared with other amaranthus species, but it was also characterised by poor seed yield and germination capacity.

\section{Acknowledgements}

The author thanks Vamile Madide, who was a research assistant during this study, and Kerry Lindsey, who assisted with the determination of antioxidant activity.

\section{References}

ALTENBACH SB and SIMPSON RB (1990) Manipulation of methionine-rich protein genes in plant seeds. Trends in Biochem. 8 156-160.

AOSA (ASSOCIATION OF OFFICIAL SEED ANALYSTS) (1993) Rules for testing seeds 16:67.

BRESSANI R (1989) The proteins of grain amaranth. Food Rev. Int. 5 13-38.

COVEY-CRUMP EM, BYKOVA NV, AFFOURTIT C, HOEFNAGEL MNH, GARDESTROM P and ATKIN OK (2007) Temperaturedependent changes in respiration rates and redox poise of the ubiquinone pool in protoplasts and isolated mitochondria of potato leaves. Physiol. Plant. 129 175-184.

FAO (1981) Amino Acid Content of Foods and Biological Data on Proteins. FAO, Rome.

FERNANDEZ SR, AYOGI S, HAN Y, PARSONS CM and BAKER D (1994) Limiting order of amino acids in corn and soybean meal for growth of the chick. Poultry Sci. 73 1887-1896.

FINCHAM JE, HOUGH FS, TALJAARD JJF, WEIDEMANN A and SCHUTTE CHJ (1986) Mseleni joint disease. Part II. Low serum calcium and magnesium levels in women. S. Afr. Med. J. 70 740-742.

GUARINO L (1997) Traditional African vegetables. Proc. IPGRI Int. Workshop on Genetic Resources of Traditional Vegetables in Africa, 29-31 August 1995. IPGRI, Nairobi. 170 pp.

JANSEN VAN RENSBURG WS, VENTER, SL, NETSHILUVHI TR, VAN DEN HEEVER E, VOSTER HJ and DE RONDE JA (2004) Role of indigenous leafy vegetables in combating hunger and malnutrition. S. Afr. J. Bot. 70 52-59.

KRUGER M, SAYED N, LANGENHOVEN M and HOLING F (1998) Composition of South African Foods: Vegetables and Fruit. Medical Research Council, Tygerberg.

LAVIGNE MB and RYAN MG (1997) Growth and maintenance respiration rates of Aspen, black spruce and jack pine stems at southern and northern Boreas sites. Tree Physiol. 17 543-551.
LINDSEY KL, MOTSEI ML and JAGER AK (2002) Screening of South African food plants for antioxidant activity. J. Food Sci. 67 2129-2131.

MANSON AD, MILES N and FARINA MPW (2004) Cedara Computerised Fertiliser Advisory Service (FERTREC). Department of Agriculture and Environmental Affairs, Cedara.

MATHENGE L (1997) Nutritional value and utilisation of traditional vegetables in Kenya. In: Guarino, L (ed.) Traditional African Vegetables. Proc. IPGRI Int. Workshop on Genetic Resources of Traditional Vegetables in Africa, 29-31 August 1995. IPGRI, Nairobi. 76-77.

MAZIBUKO TG and MODI AT (2005) Regulation of water absorption by $\mathrm{Ca}^{2+}$ osmolarity alleviates cotyledonal cracking in green beans (Phaseolus vulgaris L.). Seed Sci. Technol. 33 303-313.

MODI AT (2002). Wheat seed quality in response to molybdenum and phosphorus. J. Plant Nutr. 25 2409-2419.

MODI M, MODI AT and HENDRIKS SH (2006) Potential role for wild vegetables in household food security: a preliminary case study in KwaZulu-Natal, South Africa. Afr. J. Food Agric. Nutr. Dev. 6 $1-13$.

OLAVI K, LEA PJ, FRANCESCHI VR and EDWARDS GE (2002) Bundle sheath diffusive resistance to $\mathrm{CO}_{2}$ and effectiveness of $\mathrm{C} 4$ photosynthesis and refixation of photorespired $\mathrm{CO}_{2}$ in $\mathrm{C} 4$ cycle mutant and wild type Amaranthus edulis. Plant Physiol. 130 964-976.

PENNING DE VRIES FWT, WITLAGE JM and KREMER D (1979) Rates of respiration and of increase in structural dry matter in young wheat, ryegrass and maize plants in relation to temperature, to water stress and to their sugar content. Annals Bot. 44 595-609.

ROSS M and GRAHAM RD (1999) A new paradigm for world agriculture: meeting human needs, productive, sustainable, and nutritious. Field Crop Res. 60 1-10.

SALISBURY FB and ROSS CW (1992) Plant Physiology (4 $4^{\text {th }}$ edn.). Wardsworth, Belmont.

SMITH B (2006) The Farming Handbook. University of KwaZuluNatal Press, Pietermaritzburg.

SOIL CLASSIFICATION WORKING GROUP (1991) Soil Classification: A Taxonomic System for South Africa. Department of Agricultural Development, Pretoria.

STAHL RS and McCREE KJ (1988) Ontogenic changes in the respiration coefficients of grain sorghum. Crop Sci. 28 111-113.

STALLKNECHT GF and SCHULZ-SHAEFFER JR (1991) Amaranth rediscovered. In: Janick J and Simon JE (eds.) New Crops: Exploration, Research and Commercialisation. John Wiley \& Sons, New York 211-218.

TEUTONICO RA and KNORR D (1985) Amaranth: Composition, properties and applications of a rediscovered food crop. [Online]. Available at: http://eap.mcgill.ca/ private/vl head.htm. (Accessed on 09/07/06).

WANG SY and ZHENG W (2001) Effect of plant growth temperature on antioxidant capacity in strawberry. J. Agric. Food Chem. 49 4977- 4982.

WARDLAW IF, DAWSON I and MUNIBI P (1989) The tolerance of wheat to high temperatures during reproductive growth. II. Grain development. Aust. J. Agric. Res. 40 15-24. 
